\title{
Effect of treatment on Campylobacter pylori in peptic disease: a randomised prospective trial
}

\author{
H HUMPHREYS, S BOURKE, C DOOLEY, D MCKENNA, B POWER, \\ C T KEANE, E C SWEENEY, AND C O'MORÁIN
}

From the Departments of Clinical Microbiology and Histopathology, St James's Hospital, and Department of Gastroenterology, Meath/Adelaide Hospitals, Trinity College, Dublin, Ireland

SUMmary This study investigated the effect of colloidal bismuth subcitrate and cimetidine on Campylobacter pylori in peptic disease. In 74\% of 135 patients with peptic disease diagnosed at endoscopy $\boldsymbol{C}$ pylori was detected before treatment. Compared with cimetidine, colloidal bismuth subcitrate significantly decreased the incidence of $C$ pylori after six weeks of treatment $(p<0-001)$. In the colloidal bismuth subcitrate group, subsequent healing of the lesion was correlated with the clearance of $C$ pylori, unlike in the cimetidine group. $C$ pylori was strongly associated with the presence of histological gastritis, which was decreased by colloidal bismuth subcitrate ( $<<0.001)$.

Campylobacter pylori was first isolated from gastric mucosa by Warren and Marshall in 1983.' A number of studies have shown an association between the presence of these organisms and duodenal ulcer. ${ }^{23}$ There is a strong correlation between $C$ pylori and chronic non-autoimmune histological gastritis. ${ }^{3-5}$ The role that these organisms might play in the aetiology and pathogenesis of peptic disease remains unclear.

Colloidal bismuth subcitrate (CBS) has been used successfully in the treatment of peptic disease for over two decades. It is classified as a mucosal protecting agent but its mode of action is not fully understood. Colloidal bismuth subcitrate has an antibacterial action ${ }^{6}$ and its efficacy in the treatment of peptic disease may be explained by the eradication of $C$ pylori. Cimetidine, a $\mathrm{H}_{2}$ histamine receptor antagonist causes an increase in the gastric $\mathrm{pH}$ and may facilitate the multiplication of $C$ pylori. Neither CBS or cimetidine affect the natural history of peptic disease, but patients treated for duodenal ulcer with CBS have a lower relapse rate. ${ }^{78}$

The purpose of this study was to investigate the effect of CBS and cimetidine on $C$ pylori and histological gastritis and to determine the relationship between the presence of this bacterium and healing in patients with peptic disease.

Address for correspondence: Dr C O'Morain, Department of Gastroenterology, Meath Hospital, Dublin 8, Ireland.

Received for publication 13 August 1987.
Methods

PATIENTS

One hundred and thirty five consecutive patients undergoing endoscopy for upper gastrointestinal symptoms in whom a diagnosis of duodenal ulcer, benign gastric ulcer, endoscopic gastritis or oesophagitis was made, were entered into this study. Details of cigarette smoking and previous antacid therapy were recorded. Endoscopic gastritis was defined as macroscopic evidence of micro-ulceration, punctate haemorrhages and erythema. Two biopsies were obtained from the gastric antrum within $5 \mathrm{~cm}$ of the pylorus for microbiological and histological examination. Gastroscopy was carried out in a routine fashion with intravenous sedation after a fast of at least eight hours including medications. As previously recommended, ${ }^{6}$ patients gargled with but did not swallow a local anaesthetic spray; simethicone was not used during the procedure. Between procedures, biopsy forceps were sterilised with $2 \%$ glutaraldehyde and rinsed with tap water. There was no clinical microbiological or histological evidence to suggest crossinfection with $C$ pylori between patients. After endoscopy, patients were randomised to treatment with either cimetidine, $400 \mathrm{mg}$ PO, bd, or CBS, $5 \mathrm{ml}$ PO, qid for six weeks. Patients were reassessed clinically and endoscopically within one to two days after the end of therapy and repeat biopsies were taken. The healing of lesions seen at endoscopy was defined as re-epithelialisation of the mucosa. 


\section{HISTOLOGY}

Sections of gastric antral biopsies were stained with haematoxylin and eosin to grade the severity of histological gastritis ${ }^{2}$ and silver-impregnated by the Warthin-Starry technique to detect $C$ pylori. Histologically normal mucosa was classified as grade 0 , mucosa showing only a mild increase in mononuclear cells in the lamina propria as grade 1 , mucosa with expansion of the lamina propria by increased numbers of mononuclear cells as grade 2 and grade 3 combined features of grade 2 with acute inflammatory cells in the epithelium (active gastritis). The histopathologist was neither aware of the patients' diagnosis and treatment, nor of their order, whether before or after treatment. Three biopsies were inadequate for histological assessment.

\section{MICROBIOLOGY}

Biopsies of gastric antrum were transported to the laboratory in nutrient broth and processed within two hours of being taken. Gram's stain was done on a smear of the specimen and the biopsy was also cultured on chocolate agar at $37^{\circ} \mathrm{C}$ under microaerophilic conditions for not less than five days. Subsequent isolates were identified on the basis of colonial morphology, a Gram's stain of the isolate, positive reactions to oxidase, catalase and urease and finally, the absence of hippurate hydrolysis.

A specimen was designated as $C$ pylori positive if one or more of the three methods: Gram's stain, culture or Warthin-Starry technique was positive. The two treatment groups were analysed and compared with regard to each tabulated variable. Statistical analysis used the $\chi^{2}$ test and log linear values, with probability values $\mathrm{p}<0.05$ considered as significant. The study was approved by the hospital ethics committees.

\section{Results}

One hundred and thirty five patients entered the study at endoscopy (male to female ratio 1.7:1; mean age 41 years $[15 \cdot 13] \mathrm{SD})$. Sixty three patients were
Table 1 Incidence of Campylobacter pylori before treatment and the healing rate in the diagnostic groups

\begin{tabular}{|c|c|c|c|c|c|}
\hline \multirow[b]{2}{*}{$\begin{array}{l}\text { Endoscopic } \\
\text { diagnosis }\end{array}$} & \multirow{2}{*}{$\begin{array}{l}\text { Cpylori } \\
\text { positive } \\
\text { at entry } \\
(\%)\end{array}$} & \multicolumn{2}{|c|}{ Cimetidine } & \multicolumn{2}{|l|}{$C B S$} \\
\hline & & $\begin{array}{l}\text { Patients } \\
\text { (n) }\end{array}$ & $\begin{array}{l}\text { Healing } \\
\text { rate }(\%)\end{array}$ & $\begin{array}{l}\text { Patients } \\
(n)\end{array}$ & $\begin{array}{l}\text { Healing } \\
\text { rate }(\%)\end{array}$ \\
\hline Duodenal ulcer & 93 & 32 & 72 & 32 & 89 \\
\hline Gastric ulcer & 84 & 12 & 100 & 8 & 86 \\
\hline Oesophagitis & 61 & 15 & 47 & 13 & 42 \\
\hline Endoscopic gastrit is & 65 & 13 & 56 & 10 & 70 \\
\hline Total & 74 & 72 & 69 & 63 & 73 \\
\hline
\end{tabular}

treated with CBS and 72 with cimetidine. Seventeen patients, seven on CBS and 10 on cimetidine, were lost to follow up. These did not differ significantly in any way from those who were available for follow-up. There were no significant differences between the two treatment groups with respect to age, sex, cigarette smoking, alcohol consumption and presenting symptoms. The three latter characteristics did not change during the study.

The initial diagnoses are in Table 1: most patients had a duodenal ulcer. Cimetidine and CBS were equally effective in the treatment of peptic disease, with healing rates of $69 \%$ and $73 \%(p>0.05)$. Both agents were more effective in the treatment of peptic ulcers than of mucosal lesions. The persistent lesions in the patients with gastritis and oesophagitis had, however, improved in most. C pylori was detected as defined above in $74 \%$ of patients before treatment (Table 1). There was an excellent correlation between the three techniques with $80 \%$ of patients being positive by two or three of the methods.

$C$ pylori was isolated in almost all patients with duodenal and gastric ulcer, but the incidence was lower in oesophagitis and endoscopic gastritis (Table 1). The isolation of $C$ pylori was not significantly associated with any patient variable.

In comparison with cimetidine, there was a highly significant decrease $(82 \%-40 \%)$ in the incidence of $C$ pylori after six weeks treatment with CBS (Table $2)$. The isolation rate for the cimetidine group

Table 2 Effect of treatment on C pylori

\begin{tabular}{|c|c|c|c|c|c|c|c|}
\hline \multirow[b]{2}{*}{ Diagnostic groups } & \multicolumn{3}{|l|}{ Cimetidine } & \multicolumn{3}{|l|}{$C B S$} & \multirow[b]{2}{*}{ p Value } \\
\hline & Patients (n) & $\begin{array}{l}+ \text { Atentry } \\
(\%)\end{array}$ & $\begin{array}{l}+ \text { At } 6 \text { weeks } \\
(\%)\end{array}$ & Patients (n) & $\begin{array}{l}+ \text { Atentry } \\
(\%)\end{array}$ & $\begin{array}{l}+ \text { At6 weeks } \\
(\%)\end{array}$ & \\
\hline Duodenal ulcer & 32 & 93 & 88 & 32 & 94 & 52 & $<0.001$ \\
\hline Gastric ulcer & 12 & 92 & 75 & 8 & 71 & 48 & NS \\
\hline Oesophagitis & 15 & 50 & 48 & 13 & 78 & 33 & NS \\
\hline Endoscopic gastritis & 13 & 69 & 78 & 10 & 60 & 0 & $<0.005$ \\
\hline Total & 72 & 79 & 73 & 63 & 82 & 40 & $<0.001$ \\
\hline
\end{tabular}

NS $=$ not significant 
remained unchanged. The decreased incidence of $C$ pylori in the CBS group was significant only in duodenal ulcer and patients with endoscopic gastritis when considered separately. No patient on CBS changed from being $C$ pylori negative to positive, but seven patients on cimetidine who were initially positive became negative, while five who were initially negative became positive. The presence of $C$ pylori was directly correlated with healing in the CBS group (Table 3 ) as the chance of a lesion healing was greater if the patient was initially $C$ pylori positive. In the cimetidine group, healing was unrelated to $C$ pylori status.

There was no relationship between the presence of endoscopic and histological gastritis. Sixty seven per cent of patients had histological gastritis, the highest incidence $(74 \%)$ being in the duodenal ulcer group. The incidence in patients with gastric ulcer, oesophagitis and endoscopic gastritis was $70 \%, 56 \%$, and $61 \%$ respectively. Table 4 documents the relationship between $C$ pylori status and histological gastritis. There was a strong correlation between the presence of histological gastritis and the presence of $C$ pylori. Severe gastritis was seen in the presence of $C$ pylori but the organism was not detected in a histologically normal stomach. After six weeks of therapy with CBS, there was a significant improvement in the severity of histological gastritis (Table 5) but cimetidine had no effect on the grade of histological gastritis, however, irrespective of its effect on the primary lesion. The effect of CBS on histological gastritis was directly correlated with its ability to eradicate $C$ pylori.

\section{Discussion}

In $74 \%$ of patients with peptic disease, $C$ pylori was detected in gastric antral mucosa. This is in agreement with previous studies. ${ }^{23}$ Almost all patients with duodenal ulcer had $C$ pylori in the gastric antrum, a finding that agrees with that of Marshall and others. ${ }^{3-6}$ The presence of $C$ pylori was not associated with any epidemiological variable in this study. Five patients only had taken antibiotics in the three months before the study although none at the time of endoscopy, but such therapy does not appear to have affected $C$ pylori status. There is strong evidence that antibiotic therapy alone may be insufficient to eradicate C pylori in vivo. ${ }^{9}$

The known correlation between histological gastritis and the presence of $C$ pylori ${ }^{3-5}$ is borne out by the data presented here, where $70 \%$ of those with active gastritis were infected, while $76 \%$ of those with normal mucosa were not. The diagnosis of histological gastritis is open to subjective error or may be related to the site of sampling - for example, if the biopsy is taken from the region of a lymphoid aggregate. Therefore, it is of interest that mucosa showing intermediate grades of histological gastritis (grades 1 and 2) was found as frequently in those with as those without $C$ pylori. The ultrastructural studies of Steer, ${ }^{10-12}$ provide further evidence for the link between chronic active histological gastritis and $C$ pylori.

Many studies have documented an antibacterial effect for CBS against $C$ pylori in vitro ${ }^{6-14}$ and there are some preliminary reports of CBS having a similar effect in vivo. ${ }^{914}$ 15 The exact mode of action of CBS is unknown, ${ }^{1617}$ but it is as effective as cimetidine in the treatment of peptic ulcer disease. ${ }^{18}$ This study examined the effect of CBS, which has no systemic effects $^{16}$ on lesion healing, $C$ pylori status, and histological gastritis with a group of matched patients on cimetidine serving as a control group. The results confirm the efficacy of both agents in treating peptic disease. Colloidal bismuth subcitrate and cimetidine had different effects on $C$ pylori. Overall, the $C$ pylori status of patients on cimetidine did not change. The seven patients who lost $C$ pylori after treatment may be explained by its weak antibacterial effect $^{6}$ or sampling error. Five patients became colonised while

Table 3 C pylori status at entry and outcome in the two treatment groups

\begin{tabular}{lllll}
\hline Treatment & Outcome & $\begin{array}{l}\text { Cpylori } \\
\text { positive at } \\
\text { entry }\end{array}$ & $\begin{array}{l}\text { Cpylori } \\
\text { negative at } \\
\text { entry }\end{array}$ & p Value \\
\hline CBS & Healed & $36(88 \%)$ & $5(12 \%)$ & $<0 \cdot 001$ \\
& Unhealed & $\begin{array}{r}8(53 \%) \\
\text { Cimetidine }\end{array}$ & $\begin{array}{r}7(47 \%) \\
10(23 \%)\end{array}$ & NS \\
& Healed & $\begin{array}{l}33(77 \%) \\
(4(74 \%)\end{array}$ & $5(26 \%)$ & \\
\hline
\end{tabular}

Table 4 Correlation of $\mathrm{C}$ pylori status at entry with grade of histological gastritis (\%)

\begin{tabular}{|c|c|c|c|c|}
\hline \multirow[b]{2}{*}{ Cpylori } & \multicolumn{4}{|c|}{ Grade of histological gastritis } \\
\hline & 0 & 1 & 2 & 3 \\
\hline Present & $1(1 \%)$ & $13(13 \%)$ & $16(16 \%)$ & $69(70 \%)$ \\
\hline Absent & $25(76 \%)$ & $4(12 \%)$ & $3(9 \%)$ & $1(3 \%)$ \\
\hline
\end{tabular}

Note: three specimens could not be evaluated adequately.

Table 5 Effect of CBS on histological gastritis

\begin{tabular}{llllcl}
\hline \multirow{2}{*}{$\begin{array}{l}\text { CBS treated } \\
\text { group }\end{array}$} & $\begin{array}{l}\text { Patients } \\
(n)\end{array}$ & \multicolumn{5}{c}{ Grade of histological gastritis } \\
\cline { 3 - 6 } & $(n)$ & 1 & 2 & 3 \\
\hline At entry & 61 & 14 & 6 & 8 & 33 \\
At six weeks & 54 & 20 & 9 & 10 & 15 \\
\hline
\end{tabular}

Seven patients were lost to follow up. 
on cimetidine and this would support the assertion that $C$ pylori may be favoured by a less acid environment. The $C$ pylori status of most patients on cimetidine did not change and patient outcome whether healed or not was unrelated to the presence or absence of this organism. With CBS the incidence of $C$ pylori decreased significantly after six weeks of treatment: this was accompanied by diminished severity of histological gastritis.

The persistence of $C$ pylori was associated with an unchanged histological picture. Clearance of $C$ pylori was associated with healing of the lesion in the CBS treated patients in our study. This suggests that the healing effect of CBS may be a result of its antibacterial effect. A possible consequence of this could be if CBS is selected for treatment, the presence of $C$ pylori should be sought beforehand.

The data now accumulated strongly support a role for $C$ pylori in the pathogenesis of chronic histological gastritis which is not associated with immune mechanisms ${ }^{19}$ or excessive alkaline reflux. ${ }^{20}$ Marshall and colleagues have suggested that the ingestion of $C$ pylori induces an acute gastrointestinal disturbance which in a proportion of patients leads to chronic gastritis. ${ }^{21}$ The clinical significance of histological gastritis has yet to be determined, however, as it can be present in patients who are asymptomatic and have a normal endoscopy. This study shows a strong correlation between the presence of $C$ pylori and histological gastritis and an association between the healing of histological gastritis and the eradication of $C$ pylori on CBS only. This finding, in addition to suggesting a possible mode of action for CBS, lends support to Marshall's hypothesis.

$C$ pylori is associated with peptic disease (except oesophagitis) but it is difficult to determine its precise role in pathogenesis. Chronic antral gastritis is an almost constant feature in peptic ulcer disease..$^{22} 23$ Cpylori is often found in association but the organism has not been detected on metaplastic small intestinal type epithelium in the stomach or on normal duodenal epithelium. The intense urease activity of $C$ pylori may initiate the ulcer sequence by breaking the mucosal barrier in the stomach ${ }^{24}$ and a similar process may occur in the duodenum. By persisting in diseased mucosa, $C$ pylori may continue the ulcerogenic process because it is found in gastric metaplasia of the duodenum ${ }^{11} 12$ which is seen in endoscopically healed ulcers. ${ }^{25}$ Ulcer relapse is more common after cimetidine than CBS therapy ${ }^{78}$ possibly because CBS eradicates $C$ pylori and hence alters the natural history of the condition. Furazolidone has been shown to heal peptic ulcers and to lower the relapse rate after treatment. ${ }^{2627}$ This may imply that antibiotics should be incorporated into the management of these conditions in order to completely eradicate $C$ pylori ${ }^{28}$
While it is premature to suggest that $C$ pylori is the unifying agent in the histological gastritis-peptic ulcer spectrum, these preliminary results are exciting and suggest that a cure for peptic disease may be at hand.

We wish to thank $\mathrm{Dr}$ Colin B Blakemore for statistical analysis, Mrs Mary Foody for secretarial assistance and all the staff of the Departments of Gastroenterology, Microbiology and Histopathology, The Meath/Adelaide and St James's Hospitals for help during this study.

\section{References}

1 Warren JR, Marshall BJ. Unidentified curved bacilli on gastric epithelium in active chronic gastritis. Lancet 1983; i: 1273-5.

2 Marshall BJ, Warren JR. Unidentified curved bacilli in the stomach of patients with gastritis and peptic ulceration. Lancet 1984; i: 1311-4.

3 Price AB, Levi J, Dolby JM, et al. Campylobacter pyloridis in peptic ulcer disease: Microbiology, pathology and scanning electron microscopy. Gut 1985; 26: 1183-8.

4 Rollason TP, Stone J, Rhodes, JM. Spiral organisms in endoscopic biopsies of the human stomach. J Clin Pathol 1984; 37: 23-6.

5 Jones DM, Lessells AM, Eldridge J. Campylobacterlike organisms on the gastric mucosa: Culture, histological and serological studies. J Clin Pathol 1984; 37: 1002-6.

6 Marshall BJ, McGechie DB, Rogers PA, Glancy Ross J. Pyloric campylobacter infection and gastroduodenal disease. Med J Aust 1985; 142: 439-44.

7 Martin DF, Hollanders D, May SJ, Ravenscroft MM, Tweedle DEF, Miller JP. Difference in relapse rates of duodenal ulcer after healing with cimetidine or tripotassium dicitrato bismuthate. Lancet 1981 ; i: 7-10.

8 Hamilton I, O'Connor HJ, Wood NC, Bradbury I, Axon ATR. Healing and recurrence of duodenal ulcer after treatment with tripotassium and dicitrato bismuthate (TDB) tablets or cimetidine. Gut 1986; 27: 106-10.

9 Goodwin CS, Armstrong JA, Marshall BJ. Campylobacter pyloridis, gastritis and peptic ulceration. J Clin Pathol 1986; 39: 353-65.

10 Steer HW, Colin-Jones DG. Mucosal changes in gastric ulceration and their response to carbenoxolone sodium. Gut 1975; 16: 590-7.

11 Steer HW. Surface morphology of the gastroduodenal mucosa in peptic ulceration. Gut 1984; 25 : 1203-10.

12 Steer HW. The gastroduodenal epithelium in peptic ulceration. J Pathol 1985; 146: 355-62.

13 McNulty CAM, Dent J, Wise R. Susceptibility of clinical isolates of Campylobacter pyloridis to 11 antimicrobial agents. Antimicrobial Ag Chemother 1985; 28: 837-8.

14 Lambert JR, Hansky J, Davidson A, Pinkard K, Stockman K. Campylobacter-like organisms in vivo and in vitro susceptibility to antimicrobial and anti-ulcer therapy. Gastroenterology 1985; 88: 1462. 
15 Jones DM, Eldridge J, Whorwell PJ, Miller JP. The effect of various anti-ulcer regimens and antibiotics on the presence of Campylobacter pyloridis and it's antibody. In: Pearson AD, Skirrow MB, Lior H, Rowe B, eds. Campylobacter III. London: PHLS, 1985: 161.

16 Brogden RN, Pinder RM, Sawyer PR, Speight TM, Avery GS. Tri-potassium di-citrato bismuthate: A report on it's pharmacological properties and therapeutic efficacy in peptic ulcer disease. Drugs 1976; 12: 401-11.

17 Soutar RL, Coghill SB. Interaction of tripotassium dicitrato bismuthate with macrophages in the rat and in vitro. Gastroenterology 1986; 91: 84-93.

18 Vantrappen G, Rutgeerts P, Broeckaert L, Janssens J. Randomised open controlled trial of colloidal bismuth subcitrate tablets and cimetidine in the treatment of duodenal ulcers. Gut 1980; 21: 329-33.

19 O'Connor HJ, Axon ATR, Dixon MF. Campylobacterlike organisms unusual in Type A (pernicious anaemia) gastritis. Lancet 1984; ii: 1091.

20 O'Connor HJ, Wyatt JI, Dixon MF, Axon ATR. Campylobacter-like organisms and reflux gastritis. J Clin Pathol 1986; 39: 531-4.
21 Marshall BJ, Armstrong JA, McGechie DB, Glancy RJ. Attempt to fulfil Koch's postulates for pyloric campylobacter. Med J Aust 1985; 142: 436-9.

22 Schrager J, Spink R, Mitra S. The antrum in patients with duodenal and gastric ulcers. Gut 1967; 8: 497-508.

23 Tatsuta M, iiShi H, Okuda, S. Location of peptic ulcers in relation to antral and fundal gastritis by chemoendoscopic follow-up examinations. Dig Dis Sci 1986; 31: 7-11.

24 Hazell SL, Lee A. Campylobacter pyloridis urease, hydrogen ion back diffusion and gastric ulcers. Lancet 1986; ii: 16-7.

25 Fullman H, VanDeventer G, Scheidman D, Walsh J, Elasaoff J, Weinstein W. 'Healed' duodenal ulcers are histologically ill. Gastroenterology 1985; 88: 1390.

26 Zheng ZT, Wang ZY, Chu YZ, et al. Double blind short term trial of furazolidone in peptic ulcer. Lancet 1985; i: 1048-9.

27 Zhao HY, Li G, Gou J, et al. Furazolidone in peptic ulcer. Lancet 1985; ii: 276-7.

28 Goodwin CS, Armstrong JA. Will antimicrobial chemotherapy be efficacious for gastritis and peptic ulcer? [Leading article]. J Antimicrob Chemother 1986; 17: $1-4$. 